\title{
A mouse gene homologous to the Drosophila gene caudal is expressed in epithelial cells from the embryonic intestine
}

\author{
Philippe Duprey, ${ }^{1,3}$ Kamal Chowdhury, ${ }^{1}$ Gregory R. Dressler, ${ }^{1}$ Rudi Balling, ${ }^{1}$ Dominique Simon, ${ }^{2}$ \\ Jean-Louis Guenet, ${ }^{2}$ and Peter Gruss ${ }^{1}$ \\ 'Department of Molecular Cell Biology, Max Planck Institute for Biophysical Chemistry, Am Fassberg, 3400 Göttingen, FRG; \\ ${ }^{2}$ Unitre de Genetique de Mammiferes, Institut Pasteur, Paris 75724 Cedex 15, France
}

\begin{abstract}
A mouse gene, $C d x-1$, was isolated from an embryonic cDNA library using a Drosophila caudal gene probe. The deduced amino acid sequence of $C d x-1$ contains conserved sequence domains along the entire gene, as well as a highly conserved caudal-type homeo box. A structural comparison suggests a common ancestral origin of mouse $C d x-1$ and Drosophila caudal. The expression of $C d x-1$ during embryogenesis was analyzed by Northern blotting and in situ hybridization. $C d x-1$-specific transcripts are localized in the epithelial lining of the intestines beginning at 14 days' gestation. The expression of $C d x-1$ in the intestine continues into adulthood, but cannot be detected in any other tissues. The $C d x-1$ gene is the first homeo-box-containing gene expressed in cells derived from the embryonic endoderm.
\end{abstract}

[Key Words: caudal gene; homeo box; evolutionary conservation; intestine]

Received July 12, 1988; revised version accepted September 28, 1988.

The molecular mechanisms controlling mammalian morphogenesis are not well characterized. The study of segmentation and pattern formation has advanced, in large part, owing to genetic and molecular analyses of genes that regulate Drosophila development (for reviews, see Gehring and Hiromi 1986; Akam 1987; Scott and Carroll 1987). Structural characterization of these genes has revealed several conserved protein domains. Initially described in the Drosophila genes Antennapedia (Antp), Ultrabithorax, and fushi tarazu (McGinnis et al. 1984a; Scott and Weiner 1984), the $\sim 60$ amino acid homeo box, containing a helix-turn-helix DNA-binding motif, remains the best characterized conserved protein domain to date. In addition, more distantly related homeo-box-like sequences have been found in the maternally expressed genes caudal (Mlodzik et al. 1985) and bicoid (Frigerio et al. 1986) and the segmentation genes engrailed (en; Poole et al. 1985), paired, and gooseberry (Bopp et al. 1986).

Vertebrate genes containing Antp-type homeo boxes are present in Xenopus (Carrasco et al. 1984), mouse (for references, see Martin et al. 1987), and humans (Levine et al. 1984; Simeone et al. 1987), and two murine genes containing homology to the en homeo box also have been described (Joyner et al. 1985; Joyner and Martin 1987). Consistent with the hypothesis that murine

3Present address: INSERM U. 257, Institut Jacques-Monod, Université Paris VII, 75005 Paris, France homeo-box-containing $(\mathrm{Hox})$ genes may regulate aspects of embryogenesis, the expression of Hox genes is restricted temporally and spatially during embryogenesis (Awgulewitsch et al. 1986; Gaunt et al. 1986; Dony and Gruss 1987; Gaunt 1987; Toth et al. 1987; Utset et al. 1987; Breier et al. 1988; Featherstone et al. 1988; Holland and Hogan 1988; Le Mouellic et al. 1988; Sharpe et al. 1988; for review, see Dressler and Gruss 1988). The regulatory potential of the homeo box genes is further substantiated by their ability to bind DNA (Desplan et al. 1985; Fainsod et al. 1986; Hoey and Levine 1988) and their nuclear localization (Odenwald et al. 1987; Schulze et al. 1987).

The Drosophila caudal gene contains a homeo box different from the Antp-like sequences. First detected in oocytes as maternal transcripts, caudal mRNAs form a gradient with maximum levels at the posterior pole of the embryo. Later, maternal transcripts are replaced by newly synthesized zygotic mRNAs which also accumulate at the posterior pole (Mlodzik et al. 1985). After gastrulation, in the third-instar larvae, caudal mRNA and protein can be detected in endoderm-derived cells from the posterior midgut, hindgut, and Malpighian tubules (Mlodzik and Gehring 1987). The functional role of this gene in the generation of posterior structures was demonstrated recently by MacDonald and Struhl (1986).

If morphogenetic mechanisms are conserved through evolution, genes with homologous protein domains to other classes of Drosophila homeo box genes may be 
present in vertebrate genomes. Using a Drosophila caudal cDNA clone as a probe (Mlodzik et al. 1985), a homologous mouse gene, $C d x-1$ (Caudal-type homeo box $\mid$, was isolated and characterized. Structural similarities between $C d x-1$ and Drosophila caudal extend outside the homeo box and are colinear along the entire gene. Unlike previously described homeo-box-containing genes, $C d x-1$ expression during embryogenesis is restricted predominantly to endoderm-derived tissue. Thus, similar protein structure and embryonic expression patterns argue for a functional conservation between mouse $C d x-1$ and Drosophila caudal.

\section{Results}

\section{Isolation of murine sequences homologous to the Drosophila caudal homeo box}

To determine if the mouse genome contains sequences homologous to the caudal homeo box, Southern blots of mouse DNA, restricted with EcoRI and HindIII, were hybridized with a caudal homeo-box-containing probe. The probe used was a 304-bp SacI-PstI fragment derived from the psc335 cDNA clone (Mlodzik et al. 1985), which contains the carboxy-terminal half of the caudal homeo box and some 3'-flanking sequences, but lacks the poly(Asn) and poly(Arg) repeat stretches. When Southern blots were hybridized and washed under lowstringency conditions (see Materials and methods), multiple bands could be observed (data not shown). However, because the probe used contains the yeast mating type homology, conserved among many homeo-box-containing genes, these bands do not necessarily represent caudal-related homeo-box sequences. Indeed, it was shown previously that a caudal homeo-box probe hybridizes to multiple bands in Drosophila DNA, that are

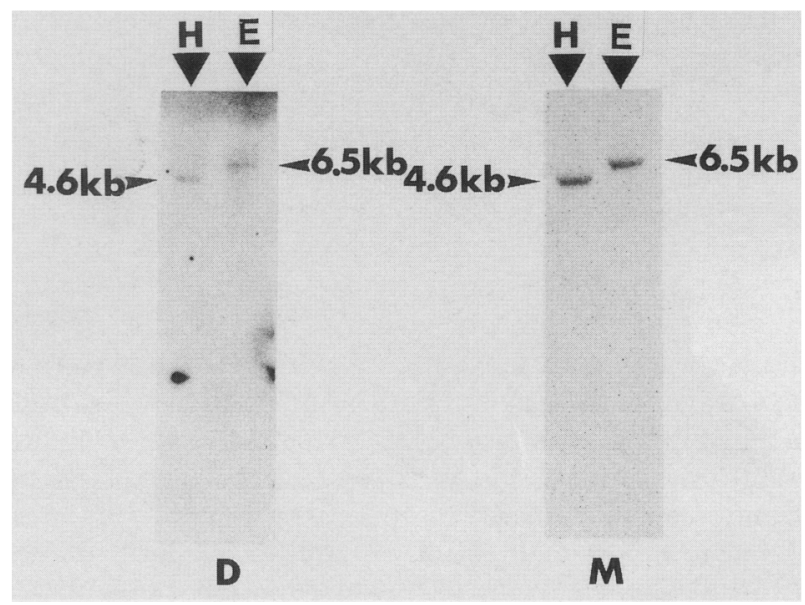

Figure 1. Identification of mouse caudal-like sequences by Southern blot hybridization. Mouse genomic DNA was digested with EcoRI (E) or HindIII (H) and hybridized with the Drosophila caudal (D) probe and the mouse BH8 cDNA clone (M). Exposure times were 10 days for $D$ and 4 days for $M$. also recognized by an Antp homeo-box probe (Mlodzik et al. 1985). Therefore, we hybridized Southern blots under high-stringency conditions and washed them under low-stringency conditions. A single band was detected in mouse DNA (Fig. 1), indicating the presence of at least one caudal-related gene.

To isolate the mouse caudal cDNA, an 8.5-day embryonic cDNA library was screened with the aforementioned Drosophila caudal probe. From $10^{6}$ plaques, 10 positive clones were isolated and the largest insert was sequenced completely. Figure 2 shows the complete nucleotide and deduced amino acid sequence of the mouse cDNA clone BH8. This cDNA contains a 573-nucleotide open reading frame, capable of encoding a 191-amino acid protein. A consensus translational initiation site (Kozak 1984) is located at position 157. However, initiation upstream of this position cannot be ruled out as no translational stop codons are located in the extremely

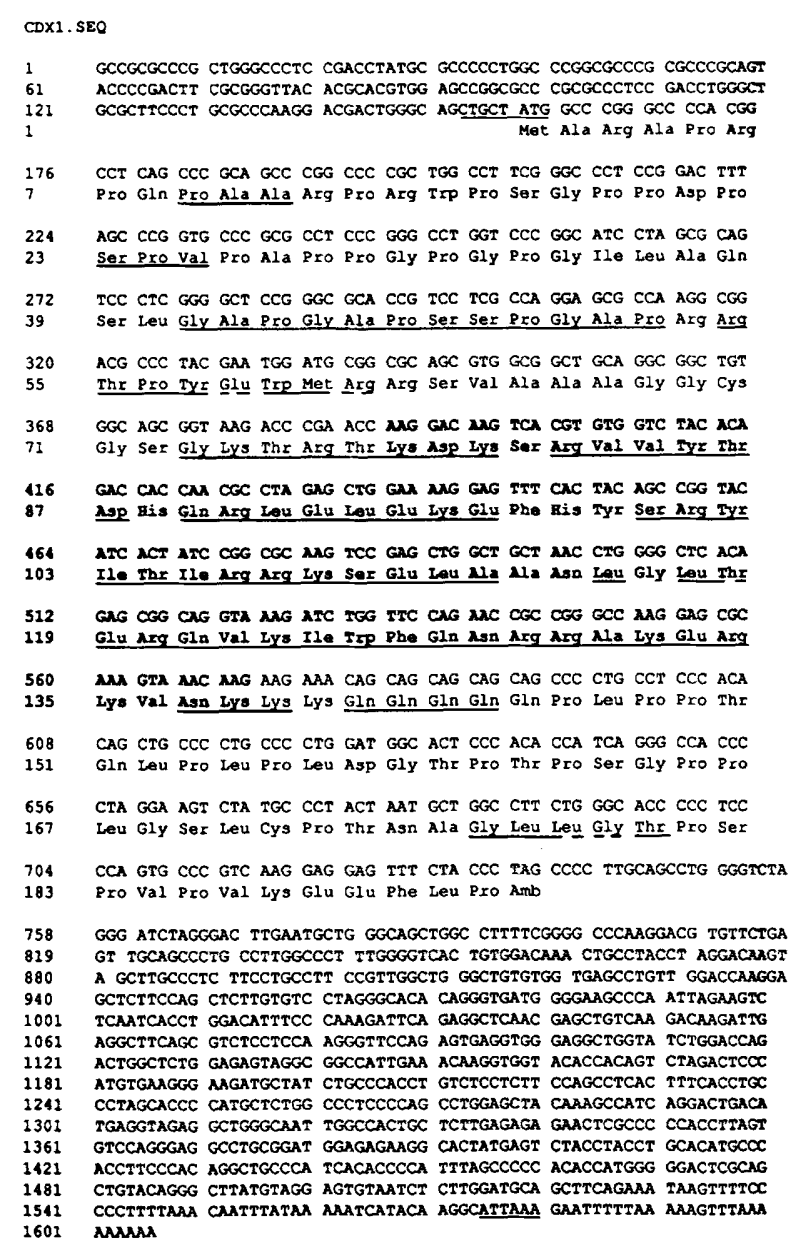

Figure 2. Nucleotide sequence and conceptual translation of the $C d x-1$ protein from the mouse BH8 cDNA clone. The homeo box domain is indicated in boldface type. Identical amino acids between mouse and Drosophila proteins are underlined in solid black and conservative changes are indicated with a dashed underline. The putative translational start site and the polyadenylation site are indicated by a thin underline. 
GC-rich 5' leader sequence. After the translational stop codon at position 731 , a long 868 -bp $3^{\prime}$-untranslated sequence follows, with a polyadenylation signal at position 1571 and a poly(A) tail at position 1594 .

\section{Comparison of the mouse Cdx-1 and Drosophila caudal proteins}

From nucleotide positions 384 to 567 , the mouse $C d x-1$ protein contains a homeo box with $76 \%$ nucleotide homology to the Drosophila caudal homeo box; nucleotide homology to the Antp homeo box is only $62 \%$. Conservation at the amino acid level between mouse $C d x-1$ and Drosophila caudal is $82 \%$ and increases to $84 \%$ if conservative amino acid substitutions are considered. Amino acid homology between mouse $C d x-1$ and Drosophila Antp is only $61 \%$, and is $67 \%$ with conservative amino acid changes included.

Many additional homologous domains between mouse Cdx-1 and Drosophila caudal are located both upstream and downstream of the homeo box, as outlined in Figure 3. They include a hexapeptide sequence of ProTyr-Glu-Trp-Met-Arg, at amino acids 55-60 of $C d x-1$, similar to the caudal Pro-Tyr-Phe-Asp-Trp-Met-Lys sequence, beginning at position 221. The homeo box is preceded by a 5-amino-acid amino-terminal extension that is identical for both the mouse and the Drosophila genes. Short conserved domains of 3 to 6 amino acids can be found along the entire mouse coding region, including the amino-terminal domains. It is of interest to note that the conserved domains are entirely colinear. Although the caudal and $C d x-1$ proteins differ in size, $46 \%$ of $C d x-1$ is conserved in the caudal gene; this figure increases to $50 \%$ if conservative substitutions are included. Thus, it appears as if the mouse gene evolved by deleting portions of the Drosophila gene, or alternatively, stretches of polyamino acids were inserted into the Drosophila gene.

\section{The Cdx-1 gene maps to mouse chromosome 18}

The method of mouse interspecies crosses was used to determine the chromosomal location of the $C d x-1$ gene (reviewed by Guenet 1986). A PstI restriction fragmentlength polymorphism (RFLP) for $C d x-1$ between C57BL/ 6 and an inbred strain of Mus spretus line SPE/Pas was utilized to determine the segregation of $C d x-1$ from a panel of back-cross progeny of (C57BL/ $6 \times \mathrm{SPE} / \mathrm{Pas}) \mathrm{F}_{1}$ females $\times \mathrm{C} 57 \mathrm{BL} / 6$ males. The chromosomal assignment of $C d x-1$ was then made by matching the segregation of the RFLP with known genetic markers. The $C d x-1$ gene is linked closely to fim2, a retroviral integration site, on chromosome 18 . Out of 31 progeny mice examined, one recombinant between $C d x-1$ and fim2 was observed. Thus, the linkage distance bewteen fim 2 and $C d x-1$ is approximately $3.2 \pm 3 \mathrm{cM}$.

\section{Cdx-1 transcripts are expressed during mouse embryonic development}

The temporal distribution of $C d x \cdot 1$ transcripts was analyzed by Northern blot hybridization. Poly $(A)+$ RNAs from 10 to 17 days post coitum (p.c.) embryos were hybridized to the BH8 cDNA clone and a single 2.2-kb $C d x-1$ transcript was detected (Fig. 4). Low levels of $C d x-1$ transcripts are first detected at 10 days p.c., decrease to undetectable levels between 11 and 14 days p.c., and increase thereafter to maximum levels at 17 days p.c. $C d x-1$ RNA levels were normalized to c-ras transcripts, whose expression is constant during embryonic development (Leon et al. 1987), to rule out effects due to RNA loading and degradation. The decrease in $C d x-1$ transcripts from 10 to 11 days p.c. cannot be accounted for by the twofold decrease in the amount of RNA loaded, because even overexposed autoradiographs do not show $C d x-1$ transcripts in RNA from 11 days p.c. embryos. Similarly, $C d x-1$ transcripts could not be detected in RNA from 14 days p.c. embryos upon long exposure. Therefore, $C d x \cdot 1$ mRNA exhibits a biphasic pattern of expression during embryonic development.

The expression of $C d x-1$ in murine embryonal carcinoma cell lines was investigated also, because these cell lines are believed to model early developmental stages (Martin 1980; Evans and Kaufman 1981). Using the $C d x$-1-specific probe, no significant hybridization could be detected to poly $(\mathrm{A})^{+}$RNAs from undifferentiated F9 and LTl cells, which are restricted in their differentiation capacities in vivo. In addition, the totipotent cell lines P19 (McBurney et al. 1982), PCC7S, and PCC4 (for review, see Nicolas et al. 1981) did not express detectable levels of $C d x-1$ transcripts.

The spatial distribution of $C d x-1$ transcripts during

\begin{tabular}{|c|c|c|c|c|c|c|c|c|}
\hline & 9 & 29 & 56 & 101 & 162 & 214 & 221 & 224 \\
\hline & $\begin{array}{l}\text { Pro-His-Ala } \\
\text { Pro-His-Gly } \\
\end{array}$ & $\begin{array}{l}\text { Ala-Ala-Ala } \\
\text { Ala-Ala-Ala }\end{array}$ & $\begin{array}{l}\text { Ser-Pro-Ala } \\
\text { Ser-Pro-Val } \\
\end{array}$ & $\begin{array}{l}\text { Gly-Ala-Pro-Gly-Ala-Pro } \\
\text { Gly-Ala-Pro-Gly-Ala-Pro }\end{array}$ & $\begin{array}{l}\text { Ser-Ser-Pro-Gly-Ala-Pro } \\
\text { Ser-Ser-Pro-Gly-Ala-Pro }\end{array}$ & $\begin{array}{l}\text { Arg-Thr } \\
\text { Arg-Thr }\end{array}$ & $\begin{array}{l}\text { Pro-Tyr } \\
\text { Pro-Tyr }\end{array}$ & $\begin{array}{l}\text { Asp-Trp-Met-Lys } \\
\text { Glu-Trp-Met-Arg } \\
\end{array}$ \\
\hline & 4 & 8 & 22 & 40 & 46 & 53 & 55 & 57 \\
\hline
\end{tabular}

\begin{tabular}{|c|c|c|c|c|c|}
\hline \multicolumn{2}{|c|}{238} & 243 & 377 & 454 & \multirow[b]{2}{*}{$\begin{array}{l}-14 \text { amino acids to termination } \\
-12 \text { amino acids to termination }\end{array}$} \\
\hline & $\begin{array}{l}\text { Gly-Lys-Thr-Arg-Thr } \\
\text { Gly Lys-Thr-Arg-Thr }\end{array}$ & $\begin{array}{l}\text { HOMEO BOX } \\
51 / 61\end{array}$ & $\begin{array}{l}\text { Gln-Leu-Gin-Gin-Gln } \\
\text { Gln-Gln-Gin-Gin-G|n }\end{array}$ & $\begin{array}{l}\text { Gly-Leu-Gly-Leu-Thr } \\
\text { Gly Leu-Leu-Gly-Thr }\end{array}$ & \\
\hline & 72 & 77 & 140 & 175 & \\
\hline
\end{tabular}

Figure 3. Schematic illustration of the homologous sequences between the mouse $C d x-1$ and Drosophila caudal proteins. The sizes of caudal and Cdx-1 are 472 and 191 amino acids, respectively. 


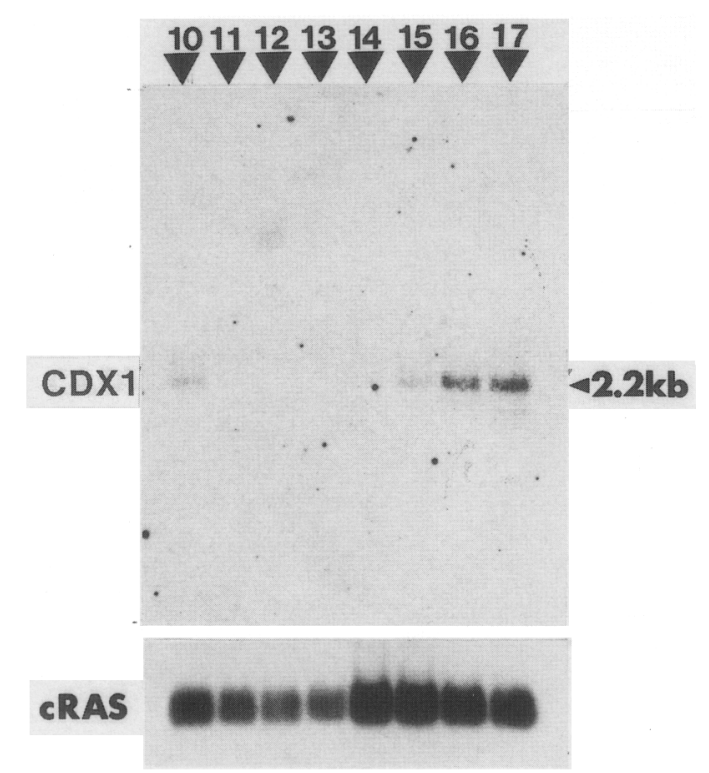

Figure 4. Northern blot analysis of $C d x-1$ transcripts in total embryonic tissue. Approximately $5 \mu \mathrm{g}$ of poly $(\mathrm{A})^{+}$RNAs from the indicated days p.c. were used. Filters were probed with $C d x-1$-specific and c-ras-specific probes as indicated. The exposure time was 8 days for the $C d x-1$ probe.

embryogenesis was analyzed by in situ hybridization to frozen sections at various developmental stages. Sections were hybridized with ${ }^{35}$ S-labeled sense and antisense $C d x-1$ RNA probes. By in situ hybridization, $C d x-1$-specific transcripts could not be detected at early and intermediate developmental stages, corresponding to $4,7,8,10$, and 12 days p.c. (data not shown). The first detectable expression of $C d x-1$ occurs at 14 days p.c. where $C d x-1$ transcripts are localized to the developing epithelial layer of the intestines, albeit the signal intensities are very weak (Fig. 5a,b). Strong hybridization to $C d x-1$ RNAs can be seen later, at 17 days p.c., and again the transcripts are restricted to the intestines (Fig. 5c-f). Specifically, $C d x-1$ transcripts are in the endoderm-derived epithelial lining and not in the smooth muscle layer $($ Fig. $5 \mathrm{~g}, \mathrm{~h})$ of the small and large intestines. Interestingly, the epithelial lining of the stomach and the duodenum do not show significant levels of $C d x-1$ hybridization (Fig. 5e,f). $C d x-1$ transcripts could not be detected in any other tissues and the $C d x-1$ sense RNA probe did not hybridize specifically at any of the developmental stages examined (data not shown).

The expression of the $C d x-1$ was also examined in adult tissues. Northern blotting experiments show two $C d x-1$ transcripts in RNA extracted from intestine (Fig. 6). A major $2.2-\mathrm{kb}$ transcript, corresponding to the embryonic mRNA, and a minor $1.7-\mathrm{kb}$ species were observed. No hybridization was obtained with RNAs extracted from lung and testis (Fig. 6), brain, heart, liver, spleen, kidney, and ovary (data not shown). As in the late embryonic stages, $C d x-1$ gene expression is restricted to the intestine.

\section{Discussion}

The mouse $C d x-1$ gene exhibits striking homology to the Drosophila caudal gene, not only in the homeo box domain, but also in upstream regions and in the carboxy-terminal region. Because of the conserved colinearity of homologous domains, it appears that either the $C d x-1$ gene was derived from a common ancestral gene by deletion of internal protein domains, or polyamino acid stretches were inserted into the Drosophila caudal gene. If there is a conservation of function between Drosophila and mouse, these polyamino acid domains may be superfluous. To a slightly lesser extent, conservation of protein domains outside the homeo box has been observed also between the Drosophila deformed (Regulski et al. 1987) and the mouse Hox-5.1 (Featherstone et al. 1988/ genes; the mouse and Drosophila engrailed genes (Joyner and Martin 1987) also exhibit amino acid homology outside the homeo box domain.

Although Drosophila caudal gene products can be detected in the oocyte, the mouse $C d x-1$ gene does not appear to be maternal as no transcripts are detected in ovaries. Drosophila caudal is also active zygotically, expressed at the posterior pole at early times during development and later in the posterior midgut, hindgut, and Malpighian tubules (Mlodzik and Gehring 1987). The mouse $C d x-1$ transcripts can only be detected by in situ hybridization in the intestines beginning at $\sim 14$ days p.c., although primitive gut development begins much earlier at 8 days p.c. $C d x-1$ transcripts could be detected at 10 days p.c. by Northern blotting of poly $(\mathrm{A})^{+}$total embryonic RNA, however these transcripts could not be localized by in situ hybridization. It is likely that the in situ hybridization method is not sensitive enough to detect the low levels of $C d x-1$ transcripts at these early times. The low frequency of $C d x-1$ cDNA clones in the 8.5-day embryonic cDNA library also indicates weak expression at this time. Although at 14 days p.c. $C d x-1$ mRNA could not be detected by Northern blotting, in situ hybridization detects weak signals in the epithelium of the developing intestines. The contribution of the $C d x-1$-expressing cells at 14 days p.c. to the total body mass is so small, less than $1 \%$, that detection by Northern blotting is unlikely. These apparent discrepancies are intrinsic to the methods used to detect $C d x-1$ transcripts. Low transcript levels are detected by Northern blotting if many cells express the gene, whereas in situ hybridization can detect transcripts in a minute population of cells provided that the RNA copy number per cell is high.

The gastrointestinal tract has diversified into the different organs - stomach, pancreas, duodenum, large and small intestine-by 14 days' gestation (see Theiler 1972). Thus, if $C d x-1$ functions in intestinal tract cell differentiation, its action must be late in the terminal differentiation process. At 16 days p.c., the large and small intestines undergo pronounced cytodifferentiation. The villi of the small intestine increase in size and form columnar epithelium, whereas the villi of the large intestine form crypts (Theiler 1972). The phenotype of the intestinal epithelium must be maintained as these 
a

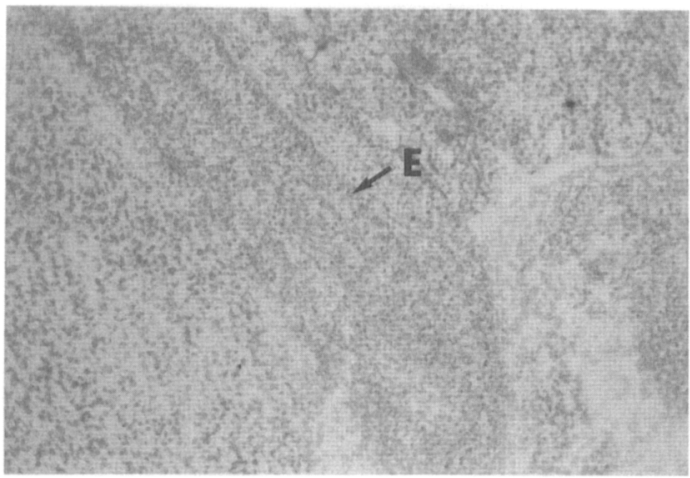

C

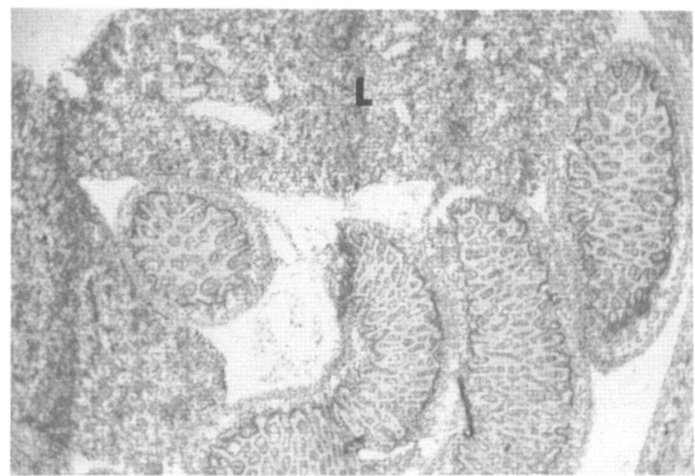

e

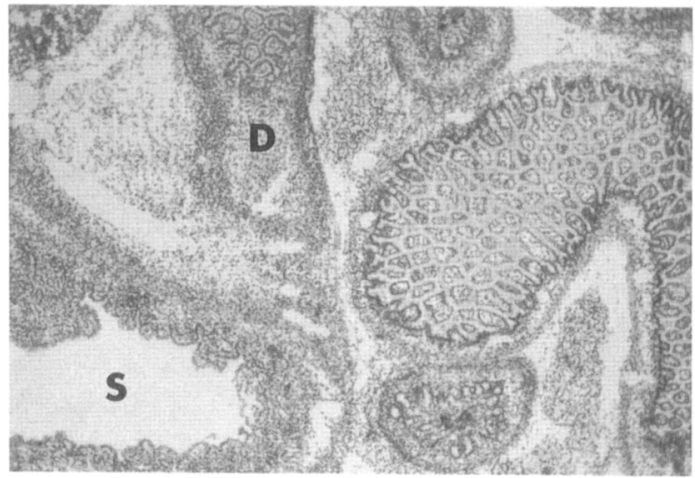

\section{g}

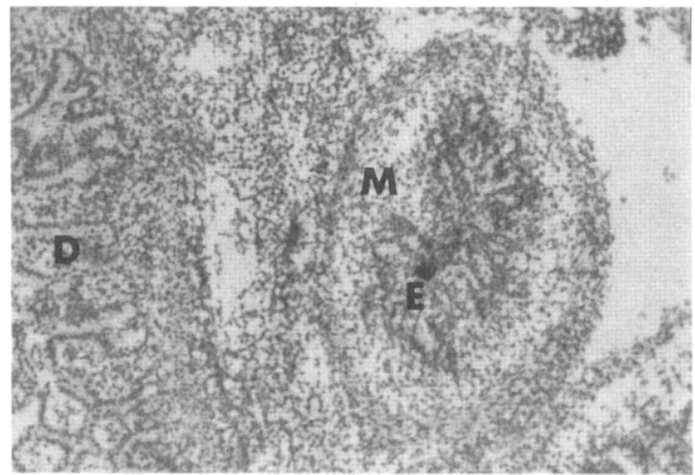

b

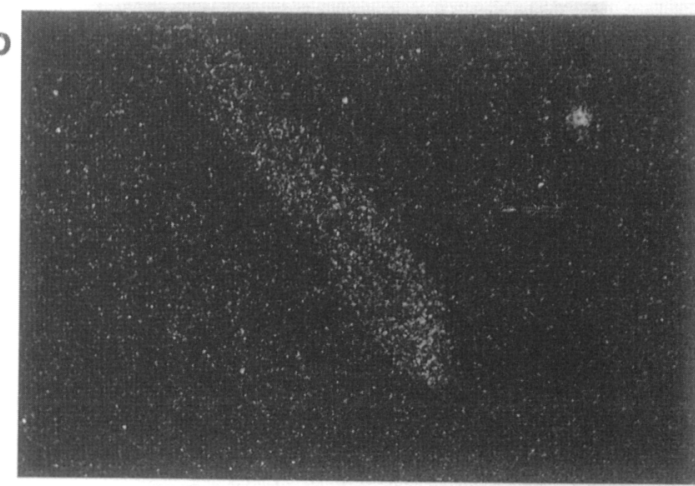

d

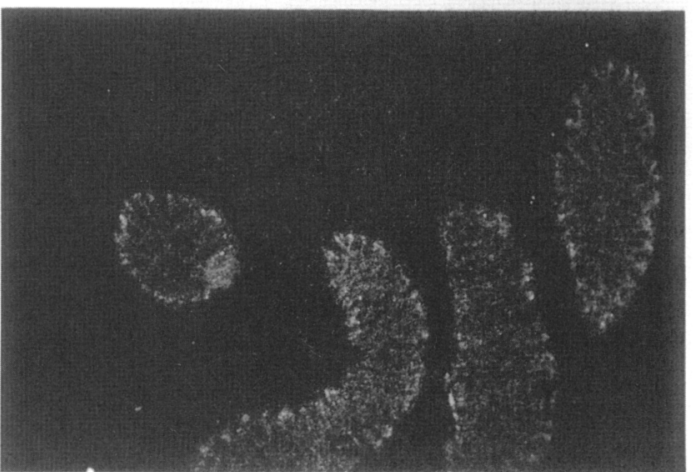

f

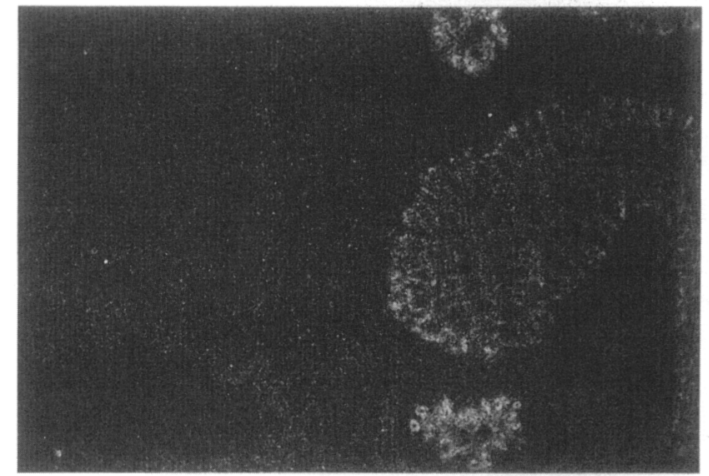

h

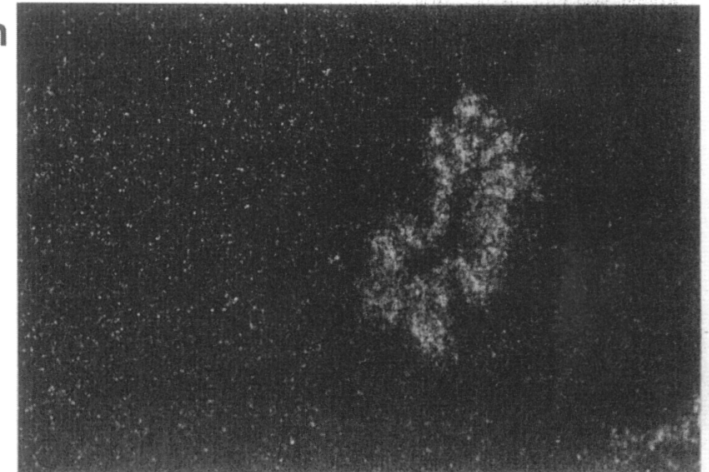

Figure 5. In situ hybridization of $C d x-1$ to mouse embryos. (a) Sagittal section through the gut of a 14 days p.c. embryo showing a developing intestine. The epithelial lining $(E)$ is indicated. Magnification, $100 \times$. (b) Dark-field image of $a$. $(c)$-Sagittal section through the gut of a 17 days p.c. embryo showing multiple transverse and longitudinal sections through the small intestine, the liver is indicated (L). Magnification, $40 \times$. (d) Dark-field image of c. (e) Parasagittal section of 17 days p.c. embryo showing the (S) stomach, (D) duodenum, and intestines. Magnification, 40×. (f) Dark-field image of $e$. (g) Cross section through the small intestine showing endoderm- (E) and mesoderm- (M) derived components. Magnification, 100×. (h) Dark-field image of $g$. 
Duprey et al.

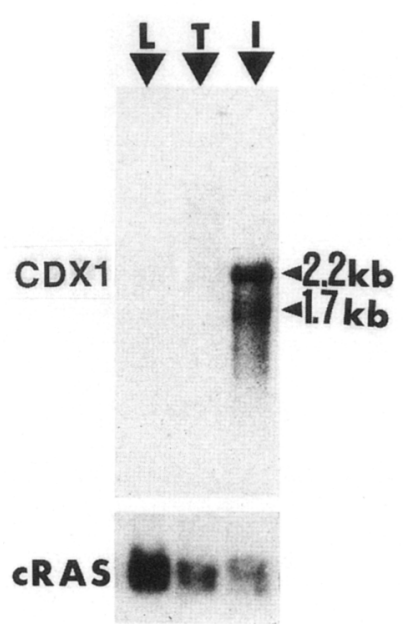

Figure 6. Detection of $C d x-1$ transcripts in adult mouse tissue. Approximately $5 \mu \mathrm{g}$ of $\operatorname{poly}(\mathrm{A})^{+}$RNA from $(\mathrm{L})$ lung, $(\mathrm{T})$ testis, and (I) intestine were electrophoresed, Northern blotted, and hybridized with $C d x-1$ - and c-ras-specific probes.

cells are undergoing continuous differentiation from stem cells (Cheng and Leblond 1974). Whether $C d x-1$ is involved directly in the differentiation process or is merely a marker for the terminal phenotype remains to be determined.

In contrast to other mouse homeo box genes, $C d x-1$ is expressed in endoderm-derived tissues. The Hox-1.3 (Dony and Gruss 1987), Hox-2.1 (Holland and Hogan 1988), Hox-5.1 (Featherstone et al. 1988), and Hox-6.1 (Sharpe et al. 1988) are expressed in the mesoderm-derived tissues of the gut, but not in the endoderm-derived portion. The Hox-1.6 gene is also expressed in intestine, although the precise location of transcripts has not been determined (Baron et al. 1987). The initial differentiation capacity of embryonic epithelium is not inherent, rather it depends on interactions with specific mesodermal mesenchyme (Rudnick 1952; Deuchar 1975). Terminal epithelium differentiation may involve the specific expression of a homeo-box-containing gene and an interaction with homeo-box-expressing mesenchyme. In fact, it has been shown using rat chimeras that terminal differentiation of intestinal epithilium requires interaction with gut mesenchyme (Kedinger et al. 1986).

The $C d x-1$ gene represents a novel type of homeo box gene in the mouse. Although it shares many structural features with the Drosophila caudal gene, $C d x-1$ is not a maternal transcript but is expressed in endoderm-derived tissues of the gut, similar to the Drosophila gene at late developmental stages. Therefore, the conservation of primary structure and aspects of the expression pattern suggest, at least in part, a conservation of function between Drosophila and mouse.

\section{Materials and methods}

Gel electrophoresis and Southern blotting

High-molecular-weight DNA was isolated from F9 embryonal carcinoma cells as described (Maniatis et al. 1982). Restriction enzyme-digested DNAs were separated on $0.8 \%$ agarose gels by electrophoresis in $1 \times$ TBE buffer and transferred to nitrocellulose filters (Schleicher \& Schull) as described (Maniatis et al. 1982). Low-stringency hybridizations to nick-translated or oligolabeled fragments (Feinberg and Vogelstein 1983) were done as described by McGinnis et al. (1984b). Low-stringency washes were performed in $2 \times \mathrm{SSC}$ with $0.1 \%$ SDS at $40^{\circ} \mathrm{C}$ for $60 \mathrm{~min}$. High-stringency hybridizations were carried out as described in Maniatis et al. (1982) in a buffer containing 50\% formamide at $42^{\circ} \mathrm{C}$. Stringent washes we carried out as follows: filters were washed in $2 \times \mathrm{SSC}$ with $0.1 \%$ SDS at $65^{\circ} \mathrm{C}$ twice for $30 \mathrm{~min}$, once in $1 \times \mathrm{SSC}$ with $0.1 \% \mathrm{SDS}$ at $65^{\circ} \mathrm{C}$ for $20 \mathrm{~min}$, and once in $0.1 \times$ SSC with $0.1 \%$ SDS at $65^{\circ} \mathrm{C}$.

\section{Screening of cDNA library in $\lambda g t 10$}

Plaques $\left(10^{6}\right)$ of an 8.5-day embryonic cDNA library (Fahrner et al. 1987/ were plated on $150-\mathrm{mm}$ petri dishes and transferred to nitrocellulose. Filters were baked at $80^{\circ} \mathrm{C}$ for $2 \mathrm{hr}$ and hybridized to nick-translated or oligolabeled probes under conditions of low or high stringency, as described for Southern blotting. High-stringency and low-stringency washes were performed as described for Southern blotting.

\section{DNA sequencing}

The nucleotide sequences were determined by the Maxam and Gilbert $(1980)$ and chain-termination methods (Sanger et al. 1977). For chain-termination sequencing, the Sequenase kit from U.S. Biochemicals was used.

\section{Isolation of RNAs from embryos and tissues and Northern blotting}

Embryos were isolated from naturally mated female NMRI mice, day 0 being equivalent to the day of the vaginal plug. RNA samples were isolated by homogenizing tissues or embryos in guanidinium thiocyanate (Chirgwin et al. 1979) and were purified by centrifugation through a $5.7 \mathrm{M} \mathrm{CsCl}, 25 \mathrm{~mm}$ sodium acetate $(\mathrm{pH} 5.0)$ cushion in a Beckman SW40 rotor at $31,000 \mathrm{rpm}$ for $22 \mathrm{hr}$. Poly $(\mathrm{A})^{+}$RNAs were obtained by retention on oligo(dT)-cellulose columns. Approximately $5 \mu \mathrm{g}$ of the respective RNAs were electrophoresed through a $1 \%$ agarose gel in $3.7 \%$ formaldehyde and MOPS $20 \mathrm{~mm}$ morpholine propane sulfonic acid, $50 \mathrm{~mm}$ sodium acetate, $10 \mathrm{mM}$ EDTA $/ \mathrm{pH}$ 7.0)] buffer. The RNAs were blotted onto a GeneScreen membrane and hybridized at $42^{\circ} \mathrm{C}$ to oligolabeled probes in $50 \%$ formamide, $5 \times$ SSPE, $5 \times$ Denhardt's, $1 \%$ SDS, and $100 \mu \mathrm{g} / \mathrm{ml}$ of denatured salmon sperm DNA.

\section{In situ hybridization}

The techniques employed for in situ hybridization were adapted from Hogan et al. (1986) with modifications as described by Dony and Gruss (1987). Embryos were frozen directly on dry ice, sectioned at $-20^{\circ} \mathrm{C}$, and dried at $55^{\circ} \mathrm{C}$ on subbed slides (Gall and Pardue 1971). Slides were fixed in $4 \%$ paraformaldehyde and dehydrated in graded ethanol. Sections were pretreated in $2 \times S S C$ at $70^{\circ} \mathrm{C}$ and digested with $0.1 \mathrm{mg} / \mathrm{ml}$ pronase. After rinsing in PBS, slides were refixed in $4 \%$ paraformaldehyde, acetylated, and dehydrated in graded ethanol.

Probes were prepared using the T3 and T7 polymerases in the Bluescript vector system (Stratagene). The $C d x-1$ cDNA fragment used for transcription extended from nucleotide 340 to 1166 (see Fig. 2). Labeled RNAs were precipitated with 10\% trichloroacetic acid and collected on nitrocellulose filters. Probes were eluted in $50 \mathrm{~mm}$ EDTA and $0.1 \%$ SDS and precipi- 
tated with ethanol. After partial alkaline hydrolysis (Cox et al. 1984), probes were resuspended to a concentration of $5 \times 10^{4}$ $\mathrm{cpm} / \mu \mathrm{l}$ in hybridization buffer (Hogan et al. 1986). Hybridization was done overnight in a humid chamber at $50^{\circ} \mathrm{C}$. Slides were washed in $50 \%$ formamide and $2 \times$ SSC, until the coverslips floated free. Sections were then subjected to RNase digestion (Ingham et al. 1985) and washed overnight in 50\% formamide and $2 \times \mathrm{SSC}$ at $37^{\circ} \mathrm{C}$. Following dehydration in graded ethanol, slides were dipped in Kodak NTB-2 emulsion, exposed for 1-2 weeks, developed, and stained with Giemsa.

\section{Acknowledgments}

We thank Walther J. Gehring and Marek Mlodzik for the Drosophila caudal probe and Brigid Hogan for the cDNA library. We thank our co-workers in the lab, particularly Urban Deutsch and Michael Kessel, for stimulating discussion and materials. We also thank Ilona Penski for preparation of the manuscript and Bernd Föhring for computer work. During the first part of this work P.D. was supported by a long-term EMBO fellowship and later by the University of Paris VII. G.R.D. is a fellow of the Alexander von Humboldt-Stiftung. This work was supported by the Max-Planck-Gesellschaft.

\section{References}

Akam, M. 1987. The molecular basis for metameric pattern in the Drosophila embryo. Development 101: 1-22.

Awgulewitsch, A., M.F. Utset, C.P. Hart, W. McGinnis, and F.H. Ruddle. 1986. Spatial restriction in expression of a mouse homeo box locus within the central nervous system. Nature 320: 328-335.

Baron, A., M.S. Featherstone, R.E. Hill, A. Hall, B. Galliot, and D. Duboule. 1987. Hox-1.6: A mouse homeo-box containing gene member of the Hox 1 complex. EMBO J. 6: 2977-2986.

Bopp, D., M. Burri, S. Baumgartner, G. Frigerio, and M. Noll. 1986. Conservation of a large protein domain in the segmentation genes paired and in functionally related genes of Drosophila. Cell 47: 1033-1040.

Breier, G., G.R. Dressler, and P. Gruss. 1988. Primary structure and developmental expression pattern of Hox 3.1, a member of the murine Hox 3 homeobox gene cluster. EMBO $J$. 7: 1329-1336.

Carrasco, A.E., W. McGinnis, W.J. Gehring, and E.M. De Robertis. 1984. Cloning of an $X$. laevis gene expressed during early embryogenesis coding for a peptide region homologous to Drosophila homeotic genes. Cell 37: 409-414.

Cheng, and C.P. Leblond. 1974. Origin, differentiation, and renewal of the four main epithelial cell types of the mouse small intestine. Am. I. Anat. 141: 537-561.

Chirgwin, J.M., A.E. Przybyla, R.J. Macdonald, and W.J. Rutter. 1979. Isolation of biologically active ribonucleic acid from sources enriched in ribonuclease. Biochemistry 18: $5294-$ 5299.

Cox, K., D. De Leon, L. Angerer, and R. Angerer. 1984. Detection of mRNAs in sea urchin embryos by in situ hybridization using asymmetric RNA probes. Dev. Biol. 101: 485502.

Desplan, C., J. Theis, and P.H. O'Farrell. 1985. The Drosophila developmental gene, engrailed, encodes a sequence-specific DNA binding activity. Nature 318: 630-635.

Deuchar, E.M. 1975. Cellular interactions in animal development. Chapman and Hall, London.

Dony, C. and P. Gruss. 1987. Specific expression of the Hox-1.3 homeo box gene in murine structures originating from or induced by the mesoderm. EMBO I. 6: 2965-2975.
Dressler, G.R. and P. Gruss. 1988. Do multigene families regulate vertebrate development? Trends Genet. 4: 214-219.

Evans, M. I. and M. H. Kaufman. 1981. Establishment of pluripotent cells from mouse embryos. Nature 317: 636-639.

Fahrner, K., B.L.M. Hogan, and R.A. Flavell. 1987. Transcription of $H-2$ and $Q a$ genes in embryonic and adult mice. $E M B O$ J. 6: 1269-1271.

Fainsod, A., L.D. Bogarad, T. Ruusala, M. Lubin, D.M. Crothers, and F.H. Ruddle. 1986. The homeo domain of a murine protein binds $5^{\prime}$ to its own homeo box. Proc. Natl. Acad. Sci. 83: 9532-9536.

Featherstone, M.S., A. Baron, S. J. Gaunt, M. G. Mattei, and D. Duboule. 1988. Hox-5.1 defines a homeobox containing gene locus on mouse chromosome 2. Proc. Natl. Acad. Sci. 85: $4760-4764$.

Feinberg, A.P. and B. Vogelstein. 1983. A technique for radiolabeling DNA restriction endonuclease fragments to high specific activity. Anal. Biochem. 132: 6-13.

Frigerio, G., M. Burri, D. Bopp, S. Baumgartner, and M. Noll. 1986. Structure of the segmentation gene paired and the Drosophila PRD gene set as part of a gene network. Cell 47: 735-746.

Gall, J. and M. Pardue. 1971. Nucleic acid hybridization in cytological preparations. Methods Enzymol. 38: 470-480.

Gaunt, S.J. 1987. Homoeobox gene Hox 1.5 expression in mouse embryos: Earliest detection by in situ hybridization is during gastrulation. Development 101: 51-60.

Gaunt, S.J., J.R. Miller, D.J. Powell, and D. Duboule. 1986. Homeobox gene expression in mouse embryos varies with position by the primitive streak stage. Nature 324: 662-664.

Gehring, W.J. and Y. Hiromi. 1986. Homeotic genes and the homeobox. Annu. Rev. Genet. 20: 147-173.

Guenet, J.-L. 1986. The gene contribution of wild-derived mouse inbred strains. Gene mapping methodology. In Topics in microbiology and immunology (ed. M. Potter, J. Nadeau, and M. Cancrol, vol. 127, pp. 109-130. SpringerVerlag, Berlin, Heidelberg, New York, Tokyo.

Hoey, T. and M. Levine. 1988. Divergent homeo box proteins recognize similar DNA sequences in Drosophila. Nature 332:858-861.

Hogan, B., F. Costantini, and E. Lacy. 1986. Manipulating the mouse embryo: A laboratory manual. Cold Spring Harbor Laboratory, Cold Spring Harbor, New York.

Holland, P.W.H. and B.L.M. Hogan. 1988. Spatially restricted patterns of expression of the homeobox containing gene Hox-2.1 during mouse embryogenesis. Development 102: $159-174$

Ingham, P., K.R. Howard, and D. Ish-Horowitz. 1985. Transcription pattern of the Drosophila segmentation gene hairy. Nature 318: 439-445.

Joyner, A.L., T. Kornberg, K.G. Coleman, D.R. Cox, and G.R. Martin. 1985. Expression during embryogenesis of a mouse gene with sequence homology to the Drosophila engrailed gene. Cell 43: 29-37.

Joyner, A.L. and G.R. Martin. 1987. En-1 and En-2, two mouse genes with sequence homology to the Drosophila engrailed gene: Expression during embryogenesis. Genes Dev. 1: 29-38.

Kedinger, M., P.M. Simon-Assman, B. Lacroix, A. Marxer, H.P. Hauri, and K. Haffen. 1986. Fetal gut mesenchyme induces differentiation of cultured intestinal endodermal and crypt cells. Dev. Biol. 113: 474-483.

Kozak, M. 1984. Compilation and analysis of sequences upstream the translational start site in eukaryotic mRNAs. Nucleic Acids Res. 12: 857-872.

Le Mouellic, H., H. Condamine, and P. Brulet 1988. Pattern of 
transcription of the homeo gene Hox 3.1 in the mouse embryo. Genes Dev. 2: 125-135.

Leon, J., I. Guerrero, and A. Pellicer. 1987. Differential expression of the ras gene family in mice. Mol. Cell. Biol. 7: 15351540.

Levine, M., G.M. Rubin, and R. Tjian. 1984. Human DNA sequences homologous to a protein coding region conserved between homeotic genes of Drosophila. Cell 38: 667-673.

Maniatis, T., E.F. Fritsch, and J. Sambrook. 1982. Molecular cloning: A laboratory manual. Cold Spring Harbor Laboratory, Cold Spring Harbor, New York.

MacDonald, P.M. and G. Struhl. 1986. A molecular gradient in early Drosophila homoeotic genes and its role in specifying the body pattern. Nature 324: 537-545.

Martin, G. R. 1980. Teratocarcinomas and mammalian embryogenesis. Science 209: 768-776.

Martin, G.R., E. Boncinelli, D. Duboule, P. Gruss, I. Jackson, R. Krumlauf, P. Lonai, W. McGinnis, F. Ruddle, and D. Wolgemuth. 1987. Nomenclature for homoeo-box-containing genes. Nature 325: 21-22.

Maxam, A.M. and W. Gilbert. 1980. Sequencing end-labeled DNA with base-specific chemical cleavages. Methods Enzymol. 65: 499-560.

McBurney, M.W., E.M.V. Jones-Villeneuve, M.K.S. Edwards, and P.J. Anderson. 1982. Control of muscle and neuronal differentiation in cultured embryonic carcinoma cell lines. Nature 299: 165-167.

McGinnis, W., M.S. Levine, E. Hafen, A. Kuroiwa, and W.J. Gehring. 1984a. A conserved DNA sequence in homeotic genes of Drosophila, Antennapedia, and Bithorax complexes. Nature 308: $428-433$.

McGinnis, W., R.L. Garber, J, Wirz, A. Kuroiwa, and W.J. Gehring. 1984b. A homologous protein-coding sequence in Drosophila homoeotic genes and its conservation in other metazoans. Cell 37: 403-408.

Mlodzik, M., A. Fjose, and W.J. Gehring. 1985. Isolation of caudal a Drosophila homeobox-containing gene with maternal expression whose transcripts form a concentration gradient at the preblastoderm stage. EMBO /. 4: 2961-2969.

Mlodzik, M. and W.J. Gehring. 1987. Expression of the caudal gene in the germ line of Drosophila: Formation of an RNA and protein gradient during early embryogenesis. Cell 48: $465-478$.

Nicolas, J.F., H. Jakob, and F. Jacob. 1981. Teratocarcinoma-derived cell lines and their use in the study of differentiation. In Functionally differentiated cell lines. Alan R. Liss, Inc., New York.

Odenwald, W.F., C.F. Taylor, F.J. Palmer-Hill, V. Friedrich, M. Tani, and R.A. Lazzarini. 1987. Expression of a homeo domain protein in noncontact inhibited cultured cells and postmitotic neurons. Genes Dev. 1: 482-496.

Poole, S.J., L.M. Kauvar, B. Dress, and T. Kornberg. 1985. The engrailed locus of Drosophila: Structural analysis of an embryonic transcript. Cell 40: 37-43.

Regulski, M., N. McGinnis, R. Chadwick, and W. McGinnis. 1987. Developmental and molecular analysis of Deformed; a homeotic gene controlling Drosophila head development. EMBO I. 6: 767-777.

Rudnick, D. 1952. Development of the digestive tube and its derivatives. Ann. N.Y. Acad. Sci. 55: 109-116.

Sanger, F., S. Nicklen, and A.R. Coulson. 1977. DNA sequencing with chain terminating inhibitors. Proc. Natl. Acad. Sci. 74: 5463-5467.

Schulze, F., K. Chowdhury, A. Zimmer, U. Drescher, and P. Gruss. 1987. The murine homeo box gene product, Hox 1.1 protein, is growth controlled and associated with chromatin. Differentiation 36: 130-137.

Scott, M.P. and A.J. Weiner. 1984. Structural relationships among genes that control development: sequence homology between Antennapedia, Ultrabithorax, and fushi tarazu loci of Drosophila. Proc. Natl. Acad. Sci. 81: 4115-4119.

Scott, M.P. and S.B. Carroll. 1987. The segmentation and homeotic gene network in early Drosophila development. Cell 51: 689-698.

Sharpe, P.T., J.R. Miller, E.P. Evans, M.P. Burtenshaw, and S.J. Gaunt. 1988. Isolation and expression of a new mouse homeobox gene. Development 102: 397-407.

Simeone, A., F. Mavilio, L. Bottero, A. Giampaolo, G. Russo, A. Faiella, E. Boncinelli, and C. Peschle. 1986. A human homeobox gene specifically expressed in spinal cord during embryonic development. Nature 320: 763-765.

Theiler, K. 1972. The house mouse. Springer-Verlag, Berlin, Heidelberg, New York.

Toth, L.E., K.L. Slawin, J.E. Pintar, and M.C. Nguyen-Huu. 1987. Region-specific expression of mouse homeo box genes in the embryonic nervous system. Proc. Natl. Acad. Sci. 84: 6790-6794.

Utset, M.F., A. Awegulewitsch, F.H. Ruddle, and W. McGinnis. 1987. Region-specific expression of two mouse homeo box genes. Science 235: 1379-1382. 


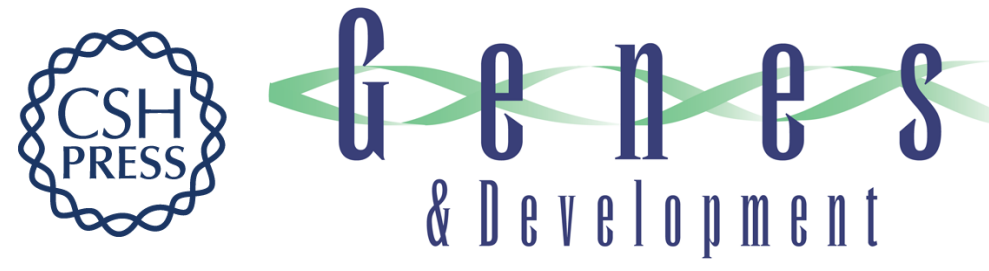

\section{A mouse gene homologous to the Drosophila gene caudal is expressed in epithelial cells from the embryonic intestine.}

P Duprey, K Chowdhury, G R Dressler, et al.

Genes Dev. 1988, 2:

Access the most recent version at doi:10.1101/gad.2.12a.1647

References This article cites 53 articles, 14 of which can be accessed free at:

http://genesdev.cshlp.org/content/2/12a/1647.full.html\#ref-list-1

License

Email Alerting

Service

Receive free email alerts when new articles cite this article - sign up in the box at the top right corner of the article or click here.

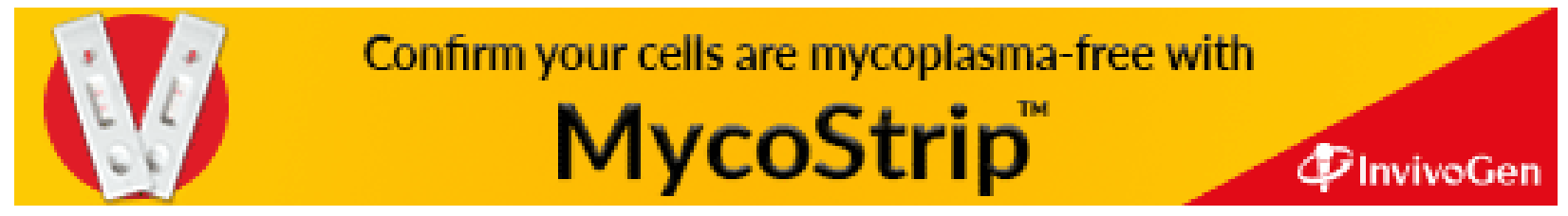

